\title{
МЕТАМОРФИЗМ, МЕТАСОМАТОЗ И РУДНАЯ МИНЕРАЛИЗАЦИЯ ПОРОД ХАРБЕЙСКОГО МЕТАМОРФИЧЕСКОГО КОМПЛЕКСА (ПОЛЯРНЫЙ УРАЛ)
}

\author{
Н. С. Уляшева \\ Институт геологии Коми НЦ УрО РАН, г. Сыктывкар \\ Поступила в редакцию 1 декабря 2018 г.
}

\begin{abstract}
Аннотация: приведены результаты петрографических, петрохимических и микрозондовых исследований в различной степени измененных амфиболитов раннепротерозойского харбейского метаморфического комплекса по руч. Скалистому, где прослеживаются процессы от ранних метаморфических до поздних рудообразуюших. Установлено, что породы претерпели два этапа метаморфизма: высоких ступеней амфиболитовой фаџии умеренньх давлений и эпидотамфиболитовой фации повыщенных давлений. Вторичные процессы клиноцоитизации, альбитизации, мусковитизациии и окварцевания характеризуют кальцчиевый, натриевый, калиевый и кремниевый уклоны метасоматических изменений. Формирование сульфидов тесно связано с оквариеванием пород. По хлориту диагностированы два этапа низкотемпературных преобразований (по рипидолиту - $245-335^{\circ} \mathrm{C}$, по пикнохлору - 135-235 ${ }^{\circ}$ ). Сульфиды представлень пиритом, халькопиритом, галенитом, сфалеритом, молибденитом и клинопирротином. Впервые в виде включений в пирите на рассматриваемой территории обнаружены - спионкопит, ковеллин, ковеллинклокманнит, а также минераль серебра и золота. Самородное золото, электрум, петровскаит и ютенбогаардтит сформировались из гипогенных низкотемпературных растворов. Акантит, гессит, акантит-гессит, науманнит-акантит, гессит-акантит-науммонит, самородное серебро, йодит и хлорид серебра образовались при наложенных гипергенных процессах.
\end{abstract}

Ключевые слова: харбейский метаморфический комплекс, метаморфизм, метасоматоз, рудная минерализация.

\section{METAMORPHISM, METASOMATISM AND ORE MINERALIZATION OF ROCKS OF THE KHARBEI METAMORPHIC COMPLEX (POLAR URALS)}

\begin{abstract}
: the results of petrographic, petrochemical and microprobe studies in varying degrees of modified amphibolites of the Kharbei metamorphic complex are presented. It was established that the rocks underwent two stages of metamorphism: high levels of amphibolite facies of moderate pressures and epidote-amphibolite facies of elevated pressures. The secondary processes of clinocitization, albitization, muscovitization and silicification characterize calcium, sodium, potassium and silica metasomatism. The formation of sulfides is closely related to the silicification of rocks. Two stages of low-temperature transformations were diagnosed for chlorite $\left(245-355{ }^{\circ} \mathrm{C}\right.$ for ripidolite, $135-255^{\circ} \mathrm{C}$ for picnochlore). The sulphides are pyrite, chalcopyrite, galenite, sphalerite and clinopyrrhotine. For the first time in the form of inclusions in pyrite in the study area found - spionkopite, covellite, covellite-klockmannite and minerals of silver and gold. Native gold, electrum, petrovskaite and yutenbogaardtite were formed from hypogenic low-temperature solutions. Acanthite, hessite, acanthite-hessite, naumannite-acanthite, hessite-acanthitenaumannite, native silver, silver iodite and silver chloride were formed during superimposed hypergene processes.
\end{abstract}

Key words: Kharbei metamorphic complex, Polar Urals, metasomatism, ore mineralization.

\section{Введение}

Метасоматические преобразования пород, приуроченные к шовным зонам, в последние годы привлекают к себе внимание в связи с возможностью выявления в них нетрадиционных источников руд- ного вещества $[1,2]$.

Харбейский метаморфический комплекс является крупным раннедокембрийским массивом в восточной части Западной тектонической зоны Полярного Урала, контактирует по разрывным нарушениям с более 
молодыми образованиями и осложнен разновозрастными разломами. В результате последних региональных работ ГДП - 200 листа Q-42-VII-VIII [3] в пределах этого комплекса были оконтурены несколько золоторудных прогнозируемых узлов. Они контролируются пересечениями северо-восточных и северозападных разломов, сопряженных часто с кайнозойским магматизмом. Благороднометалльное оруденение распространено в пропилитизированных амфиболитах и гнейсах. Золото с содержанием до 2 г/т приурочено к кварцевым жилам с вкрапленностью сульфидов и к их зальбандам, что позволило отнести оруденение к золото-сульфидно-кварцевой формации [3, 4].

Нами были изучены породы харбейского комплекса в пределах хорошо обнаженной территории по руч. Скалистому вне прогнозируемых участков, где они представлены в различной степени рассланцованными и дислоцированными измененными амфиболитами, в которых можно проследить процессы преобразования от ранних метаморфических до поздних ме- тасоматических и рудообразующих. Зона развития измененных пород контролируется разломами северозападного направления, а также надвигом северовосточной ориентировки.

Целью работы является выявление последовательности и условий метаморфических и метасоматических изменений пород руч. Скалистого, установление характера распределения и состава сульфидной и сопутствующей ей рудной минерализации.

\section{Геологическое строение}

харбейского метаморфического комплекса

Харбейский метаморфический комплекс $\left(\mathrm{PR}_{1}\right)$ расположен в южной части антиформы, слагает одноименный блок, и несогласно перекрывается рифейскими и палеозойскими отложениями (рис. 1). Взаимоотношения харбейского комплекса с окружающими отложениями тектонические $[3,5]$. Он осложнен докембрийскими и палеозойскими разломами северо-западной и северо-восточной ориентировки [3].

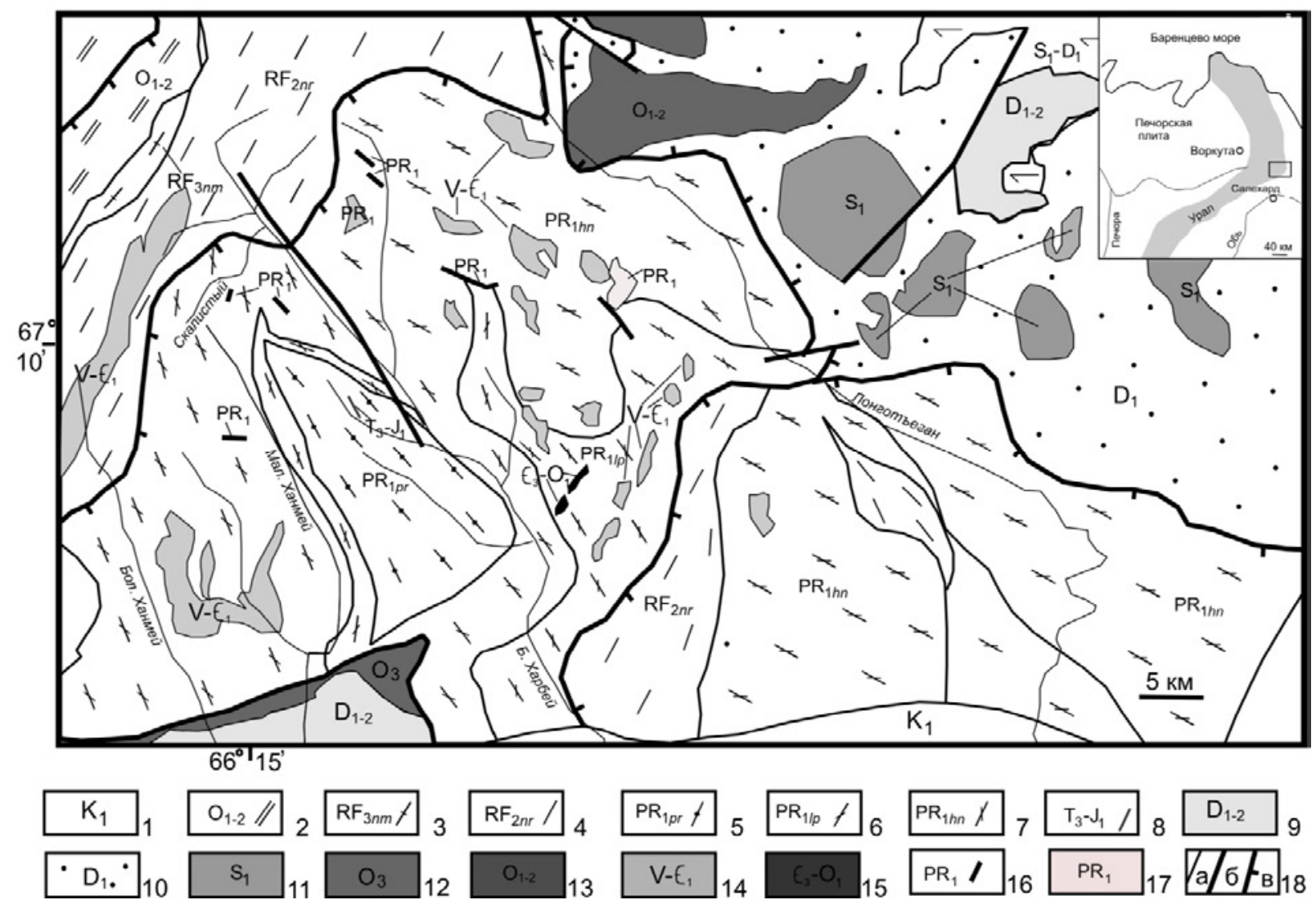

Puc. 1. Схематическая карта харбейского метаморфического комплекса (по [3]). Условные обозначения: 1 - харосоимская свита (глины, песчаники, аргиллиты); 2 - орангская свита (филлитовидные сланцы, песчаники, известняки); 3 - няровейская серия (сланцы и метабазальты верхнехарбейской и минисейшорской свит); 4 - немурюганская свита (парасланцы, мрамора, кварциты, метаэффузивы); 5-7 - харбейский метаморфический комплекс (5 - париквасьшорская свита (кристаллические сланцы, амфиболиты); 6 - лаптаюганская свита (гнейсы, мрамора, амфиболиты); 7 - ханмейхойская свита (амфиболиты, гнейсы)); 8 - Яляяхинский комплекс гипабиссальный (долериты, лампрофиры); 9 - Собский комплекс плутонический (диориты, гранодиориты, тоналиты); 10 - Юньягинский комплекс плутонический (габбро, габбродиориты); 11 - Харампейско-масловский комплекс плутонический (габбронориты); 12 - Кэршорский комплекс плутонический (дуниты, серпентиниты, габбро); 13 - Сыумкеуский дунит-гарцбургитовый плутонический комплекс (лерцолиты, гарцбургиты, дуниты); 14 - Сядатояхинский комплекс гранитовый плутонический; 15 Хартманюшорский комплекс измененных ультрамафитов; 16 - Васькеуский комплекс плутонический (метагаббро, метагаббродолериты); 17 - Евъюганский комлпекс плутонический (мигматит-плагиограниты, гранитогнейсы); 18 - разрывные нарушения: $a-$ разлом второстепенный; $\sigma$ - разлом главный, в - надвиг главный. 
Согласно результатам среднемасштабной съемки и геологического доизучения [3] рассматриваемой территории в пределах харбейского метаморфического комплекса выделяют снизу вверх следующие свиты: ханмейхойскую (амфиболиты и гнейсы) - 1500-2000 м; лаптаеганскую (амфиболиты, гнейсы, кварциты, мрамора) - 1300 м; париквасьшорскую (слюдяные кристаллические сланцы и гнейсы) - 1500 м. Границы между свитами в основном тектонические, редко согласные.

Среди интрузивных образований в харбейском комплексе широко распространены тела метагаббро и метадолеритов Васькеуского плутонического комплекса $\left(\mathrm{PR}_{1}\right)$, гранитогнейсы и мигматит-плагиограниты Евъюганского плутонического комплекса $\left(\mathrm{PR}_{1}\right)$, гипербазиты Минисейского комплекса $\left(\mathrm{RF}_{2}\right)$, граниты и гранито-гнейсы Сядатояхинского комплекca $\left(\mathrm{V}-\mathrm{C}_{1}\right)$, серпентиниты Хартманюшорского комплекса $\left(\mathrm{C}_{3}-\mathrm{O}_{1}\right)$, габбро-долериты Яляяхинского комплекса $\left(\mathrm{T}_{3}-\mathrm{J}_{1}\right)$.

Возраст комплекса считают раннепротерозойским на основании изотопно-геохимических определений - 1765 и 2071 млн. лет (Pb-Pb метод по цирконам из гранат-биотит-мусковитового сланца и гра- нат-биотитового гнейса [6]), 1730 и 2220 млн. лет (Pb-Pb метод по цирконам из гранат-амфиболового гнейса [7]).

\section{Методы исследования}

Для выявления петрографических и минералогических особенностей пород были отобраны штуфные пробы в различной степени измененных амфиболитов. Под поляризационным микроскопом в шлифах изучались взаимоотношения минералов и последовательность формирования минеральных парагенезисов. Химические состав пород выявлены с использованием метода мокрой химии и комплексного метода мокрой химии и рентгенофлуоресцентного анализа. Химические составы породообразующих и рудных минералов получены с помощью сканирующего электронного микроскопа Tescan Vega 3 LMH с энергодисперсионной приставкой Instruments X-Maх в ЦКП «Геонаука» ИГ Коми НЦ УрО РАН (аналитики Шуйский А. С., Тропников Е. М.). Термодинамические условия формирования минералов подсчитаны по гранат-амфиболовым [8, 9] и хлоритовым [10-13] геотермометрам, а также с помощью амфиболовых геобарометров $[14,15]$.

Химический состав гранатов, масс. \%

Таблица 1

Хилический состав гранапов, мacc. \%

\begin{tabular}{|c|c|c|c|c|c|c|c|c|c|}
\hline & & $\mathrm{SiO}_{2}$ & $\mathrm{Al}_{2} \mathrm{O}_{3}$ & $\mathrm{FeO}$ & $\mathrm{MnO}$ & $\mathrm{MgO}$ & $\mathrm{CaO}$ & Сумма & Формула \\
\hline \multirow{2}{*}{1} & ц & 37,45 & 21,18 & 26,18 & 4,81 & 1,24 & 9,14 & 100 & $\left(\mathrm{Fe}_{1,74} \mathrm{Ca}_{0,78} \mathrm{Mn}_{0,33} \mathrm{Mg}_{0,15}\right)_{3}\left(\mathrm{Fe}_{0,01} \mathrm{Al}_{2,00}\right)_{2,01} \mathrm{Si}_{3} \mathrm{O}_{12}$ \\
\hline & K & 37,38 & 21,04 & 27,12 & 3,37 & 1,47 & 9,62 & 100 & $\left(\mathrm{Fe}_{1,76} \mathrm{Ca}_{0,82} \mathrm{Mn}_{0,23} \mathrm{Mg}_{0,17}\right)_{2.98}\left(\mathrm{Fe}_{0,05} \mathrm{Al}_{1,98}\right)_{2,03} \mathrm{Si}_{3} \mathrm{O}_{12}$ \\
\hline \multirow{2}{*}{2} & ц & 37,18 & 20,84 & 19,66 & 12,13 & 0 & 10,12 & 100 & $\left(\mathrm{Fe}_{1,29} \mathrm{Ca}_{0,88} \mathrm{Mn}_{0,83}\right)_{3}\left(\mathrm{Fe}_{0,03} \mathrm{Al}_{1,98}\right)_{2,01} \mathrm{Si}_{3} \mathrm{O}_{12}$ \\
\hline & к & 37,17 & 21,18 & 26,99 & 3,66 & 1,5 & 9,5 & 100 & $\left(\mathrm{Fe}_{1,73} \mathrm{Ca}_{0,81} \mathrm{Mn}_{0,25} \mathrm{Mg}_{0,18}\right)_{2,97}\left(\mathrm{Fe}_{0,07} \mathrm{Al}_{1,99}\right)_{2,06} \mathrm{Si}_{3} \mathrm{O}_{12}$ \\
\hline \multirow{2}{*}{3} & ц & 37,12 & 20,87 & 20,21 & 10,23 & 0,57 & 11 & 100 & $\left(\mathrm{Fe}_{1,27} \mathrm{Ca}_{0,94} \mathrm{Mn}_{0,69} \mathrm{Mg}_{0,07}\right)_{2.97}\left(\mathrm{Fe}_{0,08} \mathrm{Al}_{1,97}\right)_{2,05} \mathrm{Si}_{3} \mathrm{O}_{12}$ \\
\hline & К & 37,42 & 20,75 & 22,39 & 7,96 & 0,66 & 10,82 & 100 & $\left(\mathrm{Fe}_{1,45} \mathrm{Ca}_{0,93} \mathrm{Mn}_{0,54} \mathrm{Mg}_{0,03}\right)_{2,95}\left(\mathrm{Fe}_{0,05} \mathrm{Al}_{1,96}\right)_{2,01} \mathrm{Si}_{3} \mathrm{O}_{12}$ \\
\hline \multirow{2}{*}{4} & ц & 34,51 & 20,22 & 28,31 & 5,59 & 1,12 & 10,25 & 100 & $\left(\mathrm{Fe}_{1,61} \mathrm{Ca}_{0,88} \mathrm{Mn}_{0,38} \mathrm{Mg}_{0,13}\right)_{3}\left(\mathrm{Fe}_{0,24} \mathrm{Al}_{1,92}\right)_{2,16} \mathrm{Si}_{2,78} \mathrm{O}_{12}$ \\
\hline & К & 34,59 & 20,36 & 29,17 & 3,62 & 1,42 & 10,84 & 100 & $\left(\mathrm{Fe}_{1,65} \mathrm{Ca}_{0,93} \mathrm{Mn}_{0,25} \mathrm{Mg}_{0,17}\right)_{3}\left(\mathrm{Fe}_{0,31} \mathrm{Al}_{1,92}\right)_{2,23} \mathrm{Si}_{2,77} \mathrm{O}_{12}$ \\
\hline \multirow{2}{*}{5} & ц & 34,93 & 19,69 & 27,59 & 5,78 & 1,29 & 10,72 & 100 & $\left(\mathrm{Fe}_{1,54} \mathrm{Ca}_{0,92} \mathrm{Mn}_{0,39} \mathrm{Mg}_{0,15}\right)_{3}\left(\mathrm{Fe}_{0,31} \mathrm{Al}_{1,87}\right)_{2,18} \mathrm{Si}_{2,81} \mathrm{O}_{12}$ \\
\hline & $\mathrm{K}$ & 35,63 & 20,71 & 28,38 & 4,11 & 1,49 & 9,68 & 100 & $\left(\mathrm{Fe}_{1,71} \mathrm{Ca}_{0,83} \mathrm{Mn}_{0,28} \mathrm{Mg}_{0,18}\right)_{3}\left(\mathrm{Fe}_{0,19} \mathrm{Al}_{1,96}\right)_{2,15} \mathrm{Si}_{2,86} \mathrm{O}_{12}$ \\
\hline \multirow{2}{*}{6} & ц & 34,74 & 20,29 & 27,26 & 5,41 & 1,28 & 11,02 & 100 & $\left(\mathrm{Fe}_{1,53} \mathrm{Ca}_{0,95} \mathrm{Mn}_{0,37} \mathrm{Mg}_{0,15}\right)_{3}\left(\mathrm{Fe}_{0,3} \mathrm{Al}_{1,92}\right)_{2,22} \mathrm{Si}_{2,79} \mathrm{O}_{12}$ \\
\hline & К & 35,19 & 20,96 & 29,3 & 3,5 & 1,56 & 9,49 & 100 & $\left(\mathrm{Fe}_{1,50} \mathrm{Ca}_{0,81} \mathrm{Mn}_{0,24} \mathrm{Mg}_{0,19}\right)_{3}\left(\mathrm{Fe}_{0,33} \mathrm{Al}_{1,98}\right)_{2,29} \mathrm{Si}_{2,82} \mathrm{O}_{12}$ \\
\hline
\end{tabular}

Примечания: 1-3 - из сланцев, 4-6 - из амфиболитов, $u$ - центр зерна, $\kappa$ - край зерна.

\section{Петрография и минералогия}

На протяжении около 4 км по руч. Скалистому от контакта с няровейской серией и вверх по течению породы харбейского комплекса представлены в различной степени дислоцированными темно-серыми гранат-хлорит-клиноцоизитовыми амфиболитами, а также серыми и зеленовато-серыми гранат-мусковиткварц-клиноцоизит-амфибол-хлорит-альбитовыми сланцами. Среди этих пород часто встречаются будины эпидозитов изометричной и удлиненной формы. По составу выделяются амфибол-клиноцоизитовые, хлорит-кварц-клиноцоизитовые (рис. 2 а), мусковитхлорит-кальцит-кварц-клиноцоизитовые эпидозиты. Амфиболиты, сланцы и эпидозиты пересекаются кварцевыми, кальцитовыми, хлорит-кальцитовыми прожилками (рис. 2 б) и кварцевыми жилами.

Гранат-хлорит-клиночоизитовые амфиболить имеют сланцеватую текстуру, порфиробластовую и гранонематобластовую структуру (рис. 2 в). Основными минералами в них являются амфибол - барруазит (50-70\%), альбит (до $20 \%$ ) и клиноцоизит (до 10\%). В породах встречаются кварц (до 1\%), гранат (1-3\%), хлорит (до 5\%) и мусковит (до 2\%). Акцессорные минералы представлены кальцитом, цирконом, апатитом и титанитом, рудные - магнетитом и пиритом.

Амфибол представлен в основном длиннопризматическим зеленым и голубовато-зеленым барруазитом (рис. 3 а) [16]. По краям минерал замещается хлоритом. На контакте с клиноцоитизированными участками в породе появляются светло-зеленая призматическая магнезиальная роговая обманка (рис. 3 б). Изредка в барруазите отмечаются реликты эденита (рис. 3 в). Слабо розовые порфиробласты граната имеют идиоморфные зерна, содержат включения клиноцоизита 


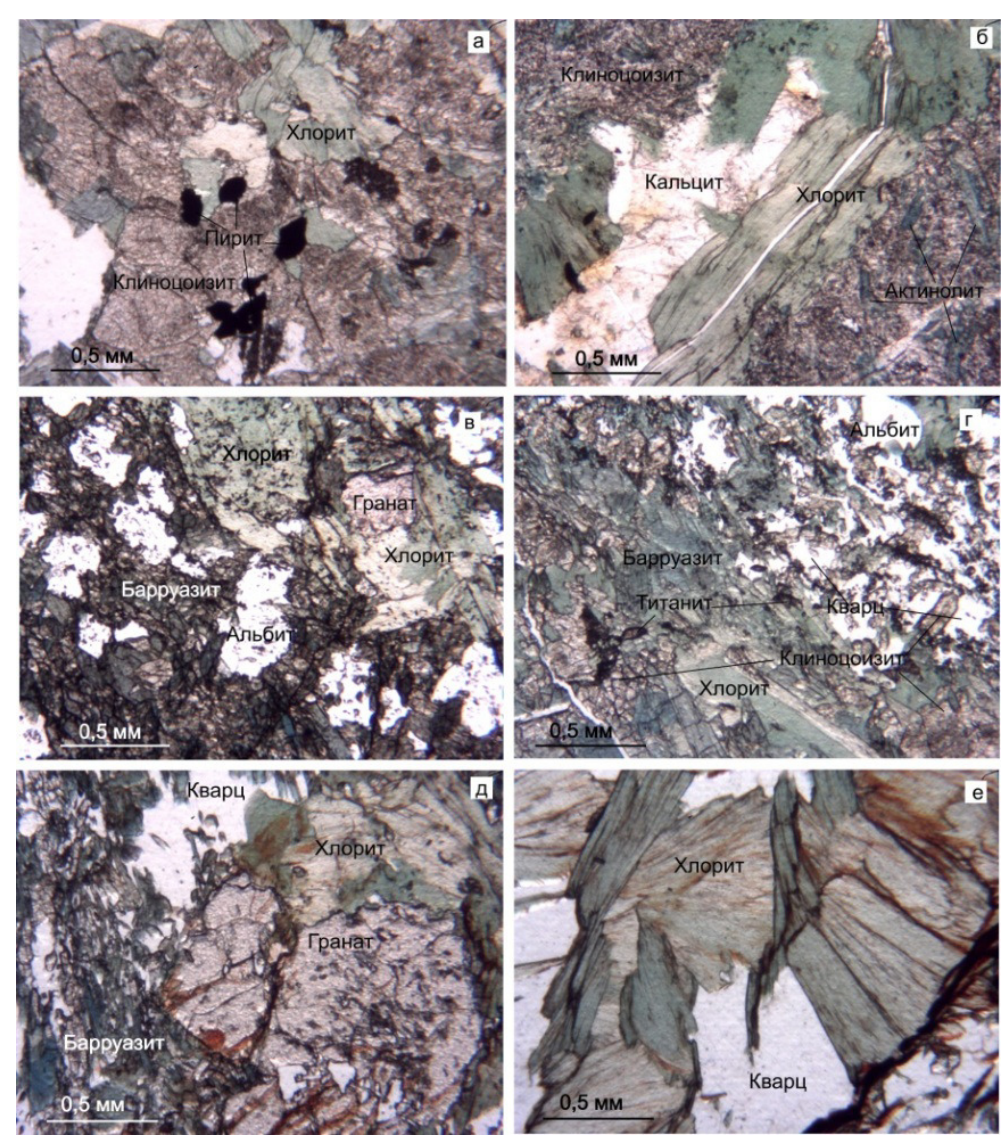

Puc. 2. Фотографии шлифов пород руч. Скалистого: $a$ - хлорит-кварцклиноцоизитовая порода с зернами пиритов; $\sigma$ - хлорит-кальцитовый прожилок в актинолит-клиноцоизитовой породе (в эпидозите); 8 - гранат-хлоритклиноцоизитовый амфиболит, г - полосчатый кварц-хлорит-клиноцоизитальбитовый сланец, $\partial$ - замещение граната хлоритом, $e$ - сноповидные агрегаты хлорита.

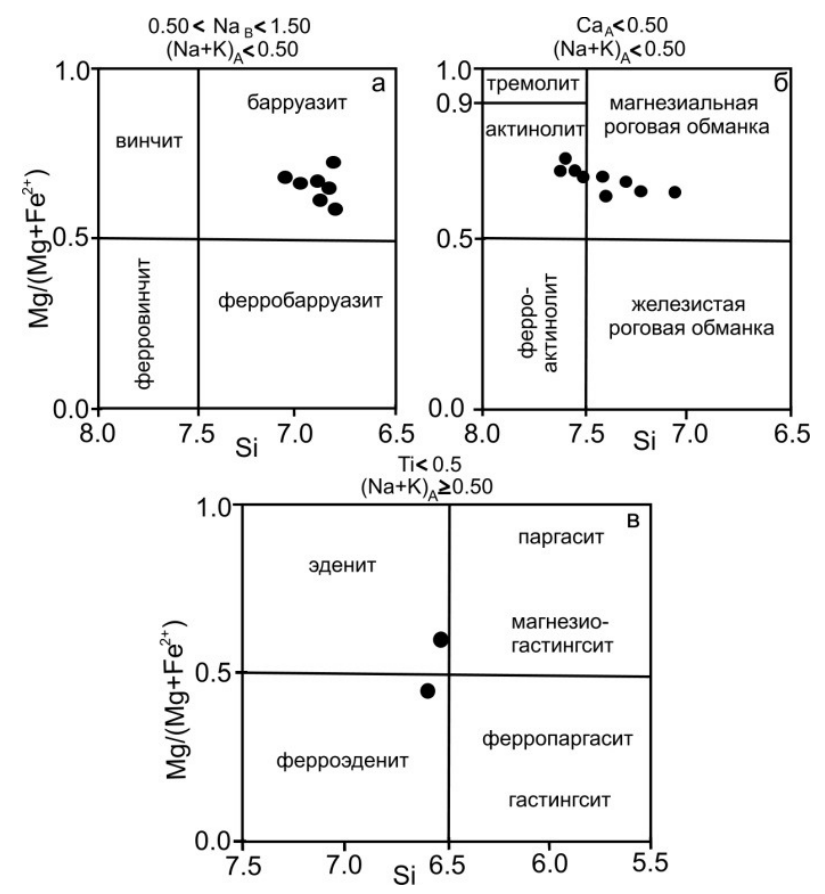

Pис. 3. Точки составов амфиболов (а - барруазиты, б - манезиальные роговые обманки и актинолиты, в - эдениты) из пород харбейского комплекса по руч. Скалистому на диаграмме Лика [16]. и альбита. В них наблюдается прогрессивная зональность: уменьшение марганца и увеличение магния и железа от центра к периферии кристаллов (табл. 1). Альбит образует линзовидной и неправильной извилистой формы порфиробласты с гелицитовой структурой с включениями клиноцоизита и амфибола. Хлорит и мусковит встречается в виде крупных чешуек, часто развивается поперек сланцеватости и ассоциируется с титанитом. Магнетит равномерно распределен по породе в виде идиоморфных зерен.

Сланцы имеют полосчатую, плойчатую, сланцеватую текстуру и порфиробластовую, гранонематобластовую структуру (рис. 2 г). В них по сравнению с амфиболитами повышается содержание кварца (до 15\%), хлорита (до 15\%), альбита (до $20 \%$ ), актинолита (магнезиальной роговой обманки) (до 20\%), мусковита и клиноцоизита (до 20\%). Эти минералы в сланцах содержатся в переменном количестве. Полосчатость обусловлена перераспределением минералов в отдельные прослои различной мощности от 0,5 мм до $10 \mathrm{~cm}$. Наблюдаются мономинеральные прослои - гранатовые, хлоритовые, мусковитовые и кварцевые. К осветленным полосам приурочены линзообразные и прожилкообразные выделения кварца. В качестве акцессорных минералов в породах встречаются, апатит, циркон и титанит. В сланцах присутствует магнетит и широко проявлена сульфидизация.

Амфибол представлен барруазитом, актинолитом и магнезиальной роговой обманкой. В них изредка встречаются реликты ферроэденита (рис 3 в). Гранат образует порфиробласты, нередко имеющие пойкилобластовую структуру и структуру снежного кома. Включения в гранате представлены клиноцоизитом. Минерал по трещинкам и краям замещается хлоритом.

Альбит представлен двумя генерациями. Альбит I образует линозовидной и неправильной формы порфиробласты с гелицитовой структурой с включениями клиноцоизита и барруазита. Альбит II имеет порфиробласты таблитчатой формы часто с простым двойникованием с включениями кварца и эпидота, замещает вторичный хлорит. Клиноцоизит встречается также в виде двух генераций. Призматические изометричные небольшого размера (до 0,3 мм) зерна I генерации в основной массе парагенетически связаны с барруазитом и гранатом. Новообразованные более крупные (до 0,8 мм) идиоморфные и 
изометричные с извилитыми краями образования представлены клиноцоизитом II. Кварц также представлен более ранней генерацией в виде небольших неправильных зерен в ассоциации с альбитом I и поздней генерацией II в осветленных прослоях, прожилках, линзообразных выделениях и жилах, замещает альбит II. Хлорит представлен в основном рипидолитом, замещает гранат и барруазит по краям (рис. 2 д), развивается вдоль трещинок и образует сноповидные агрегаты (рис. 2 е). Такие формы выделения хлорита могут указывать на его метасоматическую природу. Высокожелезистый пикнохлор изредка наблюдается в виде включений в пирите. Титанит образует идиоморфные зерна и находится в ассоциации с хлоритом.

Судя по взаимоотношениям минералов актинолит, магнезиальная роговая обманка, кальцит, хлорит, клиноцоизит II, альбит I, альбит II, мусковит и кварц II в сланцах являются вторичными образованиями по отношению к барруазиту, кварцу I и гранату, поэтому рассматриваемые породы можно классифицировать как измененные амфиболиты.

\section{Петрохимия}

Анализ содержаний породообразующих оксидов (табл. 2) в слабо измененных вторичными процессами массивных и сланцеватых амфиболитах центральных частей харбейского метаморфического комплекса и в породах руч. Скалистого показало, что последние, за исключением окварцованных разновидностей, имеют пониженные содержания кремнезема (44,94-49,78\%) по сравнению с массивными и сланцеватыми амфиболитами $\quad(48,99-52,22 \%)$. Гранат-хлорит-клиноцоизитовые амфиболиты (табл. 2, № 5-8) близки по химическому составу к массивным (табл. 2, №1, 2) и сланцеватым амфиболитам (табл. 2, № 3, 4). Кварц-клиноцоизитамфибол-хлорит-альбитовые сланцы и некоторые амфиболиты (табл. 2, №7, 9) характеризуются повышенным содержанием оксида натрия (6,07-6,19\%). В породах (табл. 2, № 10-12), где проявлена мусковитизация, наблюдаются повышение содержания глинозема $(14,7-$ $18,04 \%)$ и оксида калия $(0,21-0,41 \%)$. В полосчатых сланцах (табл. 2, № 13, 14), в которых развиваются

Химический состав пород харбейского метаморфического комплекса, масс.\%

\begin{tabular}{|c|c|c|c|c|c|c|c|c|c|}
\hline \multirow{2}{*}{ Компоненты } & 1 & $2^{*}$ & $3^{*}$ & $4^{*}$ & 5 & 6 & 7 & 8 & $9^{*}$ \\
\hline & $13-1$ & $13-10$ & $16-1$ & $16-3$ & $106-8$ & $107-1$ & $107-3$ & $107-8$ & $107-2$ \\
\hline $\mathrm{SiO}_{2}$ & 50,06 & 48,89 & 49,52 & 52,22 & 45,66 & 46,14 & 47,13 & 52,76 & 46,6 \\
\hline $\mathrm{TIO}_{2}$ & 1,92 & 2,1 & 1,82 & 0,96 & 1,51 & 1,31 & 1,31 & 1,44 & 1,29 \\
\hline $\mathrm{Al}_{2} \mathrm{O}_{3}$ & 12,67 & 12,12 & 13,29 & 13,71 & 13,14 & 13,14 & 12,11 & 12,77 & 14,23 \\
\hline $\mathrm{Fe}_{2} \mathrm{O}_{3}$ & 6,8 & 6,53 & 5,38 & 1,44 & 8,19 & 4,39 & 4,68 & 3,63 & 6,2 \\
\hline $\mathrm{FeO}$ & 8,07 & 9,76 & 9,14 & 6,11 & 7,97 & 11,1 & 10,36 & 9,49 & 8,57 \\
\hline $\mathrm{MnO}$ & 0,18 & 0,16 & 0,23 & 0,23 & 0,19 & 0,27 & 0,17 & 0,29 & 0,19 \\
\hline $\mathrm{MgO}$ & 4,99 & 5,94 & 10,36 & 10,36 & 6,16 & 6,76 & 7,8 & 6,35 & 6,92 \\
\hline $\mathrm{CaO}$ & 8,21 & 9,59 & 10,09 & 10,05 & 11,33 & 7,96 & 6,76 & 7,2 & 6,15 \\
\hline $\mathrm{Na}_{2} \mathrm{O}$ & 4,48 & 1,97 & 2,49 & 2,48 & 2,7 & 4,58 & 6,19 & 3,36 & 6,07 \\
\hline $\mathrm{K}_{2} \mathrm{O}$ & 0,36 & 0,58 & 0,55 & 0,33 & 0,13 & 0,22 & 0,1 & 0,11 & 0,19 \\
\hline $\mathrm{P}_{2} \mathrm{O}_{5}$ & 0,42 & 0,12 & 0,21 & 0,01 & 0,14 & 0,12 & 0,05 & 0,01 & 0,11 \\
\hline П.П.П & 0,6 & 2,23 & 2,11 & 2,09 & 1,33 & 2,04 & 1,26 & 2,6 & 2,82 \\
\hline Сумма & 99,64 & 100 & 100 & 100 & 99,25 & 99,25 & 99,05 & 100 & 100,28 \\
\hline $\mathrm{CO}_{2}$ & не опр. & не опр. & не опр. & не опр. & 0,1 & не опр. & не опр. & не опр. & не опр. \\
\hline $\mathrm{S}_{\text {обш }}$ & не опр. & не опр. & не опр. & не опр. & 0,1 & не опр. & не опр. & не опр. & не опр. \\
\hline \multirow{2}{*}{ Компоненты } & 10 & $11^{*}$ & $12^{*}$ & 13 & 14 & 15 & 16 & 17 & 18 \\
\hline & $107-6$ & $107-7$ & $x-106$ & 106-3 & $106-1$ & 106-2 & $106-7$ & $106-10$ & $107-9$ \\
\hline $\mathrm{SiO}_{2}$ & 44,94 & 48,84 & 47,66 & 53,12 & 59,92 & 51,66 & 49,78 & 48,06 & 48,16 \\
\hline $\mathrm{TIO}_{2}$ & 0,83 & 1,05 & 1,32 & 1,79 & 0,85 & 0,87 & 1,18 & 2,23 & 1 \\
\hline $\mathrm{Al}_{2} \mathrm{O}_{3}$ & 16,57 & 18,04 & 14,7 & 10,29 & 11,79 & 14,82 & 14,79 & 12,6 & 12,78 \\
\hline $\mathrm{Fe}_{2} \mathrm{O}_{3}$ & 4,28 & 3,56 & 4,08 & 3,81 & 3,78 & 6,4 & 7,32 & 7,79 & 6,6 \\
\hline $\mathrm{FeO}$ & 9,68 & 7,25 & 8,12 & 10,87 & 7,54 & 3,56 & 4,71 & 2,84 & 2,7 \\
\hline $\mathrm{MnO}$ & 0,21 & 0,11 & 0,18 & 0,24 & 0,33 & 0,13 & 0,15 & 0,14 & 0,22 \\
\hline $\mathrm{MgO}$ & 7,96 & 6,74 & 6,54 & 6,68 & 5,09 & 2,49 & 4,03 & 2,12 & 1,92 \\
\hline $\mathrm{CaO}$ & 9,45 & 6,26 & 8,71 & 8,13 & 3,57 & 15,73 & 13,9 & 17,2 & 19,19 \\
\hline $\mathrm{Na}_{2} \mathrm{O}$ & 2,68 & 4,31 & 3,84 & 0,94 & 2,27 & 0,31 & 0,97 & 0,2 & 0,53 \\
\hline $\mathrm{K}_{2} \mathrm{O}$ & 0,21 & 0,37 & 0,41 & 0,12 & 0,15 & 0,08 & 0,23 & 0,06 & 0,05 \\
\hline $\mathrm{P}_{2} \mathrm{O}_{5}$ & 0,07 & 0 & 0,15 & 0,22 & 0,094 & 0,074 & 0,17 & 0,56 & 0,09 \\
\hline п.п.п & 3,12 & 3,46 & 2,65 & 2,09 & 3,45 & 2,68 & 1,58 & 5,1 & 6,39 \\
\hline Сумма & 100 & 100 & 99,17 & 99,39 & 99,17 & 99,16 & 99,28 & 99,18 & 99,88 \\
\hline $\mathrm{CO}_{2}$ & не опр. & не опр. & 0,81 & 0,1 & 0,1 & 1,02 & 0,1 & 2,66 & 5,09 \\
\hline $\mathrm{S}_{\text {общ }}$ & не опр. & не опр. & 0,45 & 0,12 & 1,08 & 0,12 & 0,15 & 0,1 & 0,1 \\
\hline
\end{tabular}

Примечания к табл. 2: 1-4-амфиболиты центральной части харбейского комплекса (1,2 - массивные амфиболиты, 3-4 - сланцеватые амфиболиты); 5-18 - породы руч. Скалистого (5 - 8 - гранат-хлорит-клиноцоизитовые амфиболиты, 9 - клиноцоизитамфибол-хлорит-альбитовый сланец, 10-12 - клиноцоизит-хлорит-мусковит-альбит-амфиболовый сланец, 13-14 - полосчатые окварцованные сланцы; 15-18 - клиноциотизированные породы (эпидозиты). Номера без звездочки - метод мокрой химии, номера со звездочкой - комплексный метод мокрой химии и рентгенофлуоресцентного анализа. 
прослои, прожилки и линзообразные выделения кварцевого состава, увеличивается содержание кремнезема $(51,66-$ 59,92\%). Преимущественно клиноцоизитовые и кальцитизированные разновидности пород (табл. 2, № 15-18) имеют пониженные содержания закисного железа (2,7-4,71\%), оксида магния (1,92-4,03\%), оксида натрия $(0,2-0,97 \%)$ и повышенные содержания оксида кальция $(13,9-19,19 \%)$.

\section{Рудная минерализация}

В изучаемых сланцах руч. Скалистого широко проявлена вкрапленная и прожилково-вкрапленная сульфидная минерализация. На микрозондовом анализаторе были изучены рудные минералы в хлоритизированных эпидозитах и окварцованных сланцах. Сульфиды представлены в основном пиритом и халькопиритом. Сфалерит, галенит, молибденит, пентландит и клинопирротин встречаются в виде включений в пирите. Впервые выявлены в пиритах рассматриваемых пород спионкопит $\left(\mathrm{Cu}_{1,32} \mathrm{~S}\right)$, ковеллин, ковеллин-клокманнит, кобальтсодержащий пентландит, а также минералы серебра и золота (табл. 3). Минеральные виды некоторых сульфидов (молибденит, галенит, ковеллин, ковеллин-клокманнит) и в основном фаз серебра и золота установлены в результате пересчета полученных данных на нормативно-минеральный состав, так как из-за их очень мелких размеров на результаты анализов влияет состав окружающей матрицы. Выявлены минералы, близкие по составу к акантиту, гесситу, акантит-гесситу, науммонит-акантиту, гессит-акантит-науммониту, ютенбогаардтиту $\left(\mathrm{Ag}_{3} \mathrm{AuS}_{2}\right)$, петровскаиту $(\mathrm{AuAg}(\mathrm{S}, \mathrm{Se}))$, высокопробному золоту, самородному серебру, хлориду и йодиду серебра (табл. 4). В породах установлено присутствие электрума и низкопробного золота (табл. 5).

Пирит наблюдается в полосчатых сланцах и хлоритовых эпидозитах. Его количество и размеры (до 1 см и более) возрастают вблизи линзовидных выделений кварца. Минерал образует хорошо ограненные кубические идиоморфные зерна, а также неправильной формы выделения. Пирит содержит включения хлорита, титанита, эпидота, халькопирита, галенита, ковеллин-клокманнита, клинопирротина, сфалерита, пентландита, спионкопита, акантит-гессита, акантита и гессита. Иногда содержит примесь никеля. По его краям и трещинкам развиваются гидроокислы железа в ассоциации с наумманит-акантитом и акантитом.

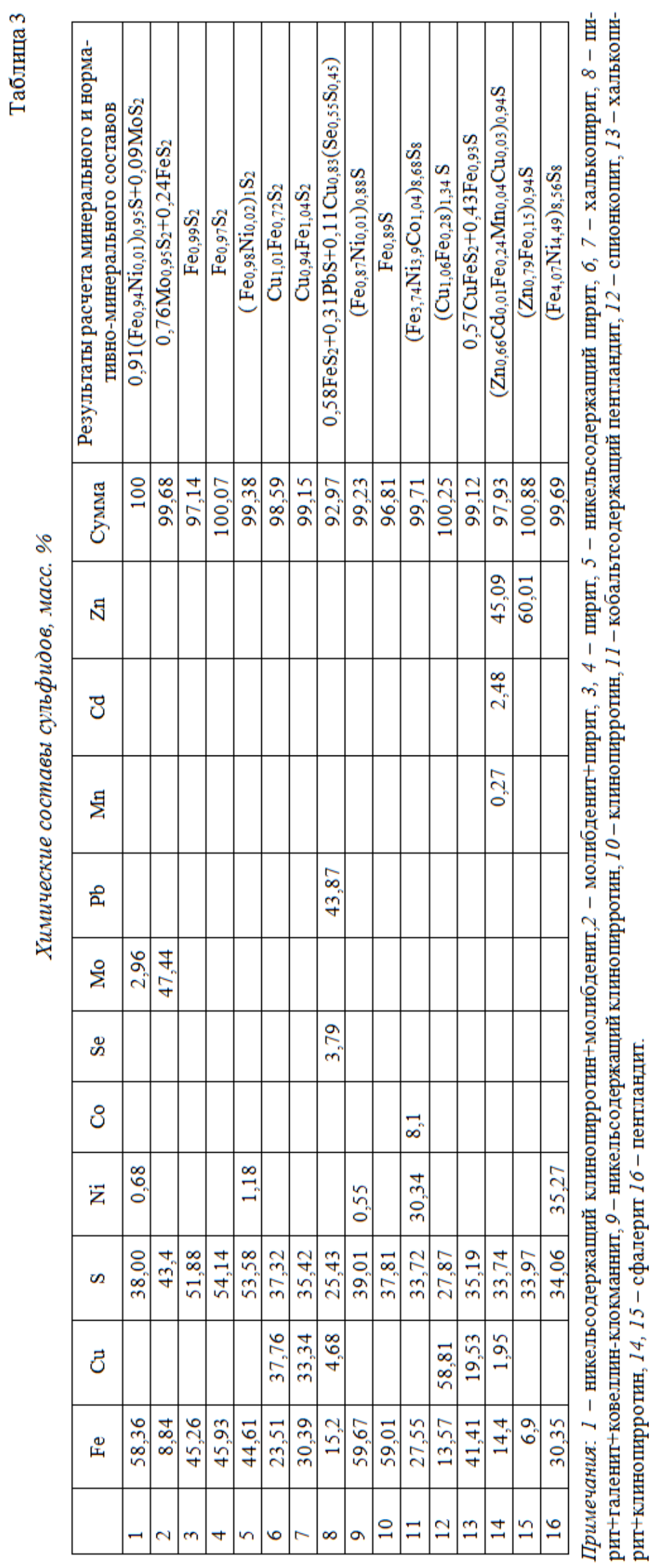




\begin{tabular}{|c|c|c|c|c|c|c|c|c|c|c|c|c|c|c|c|}
\hline 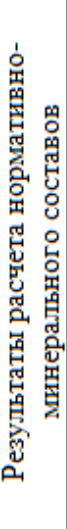 & 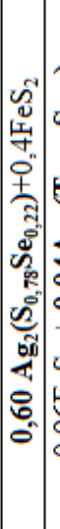 & 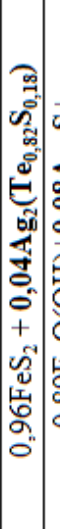 & 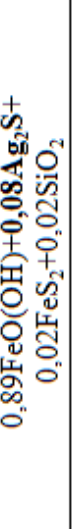 & 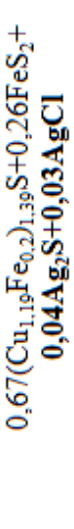 & 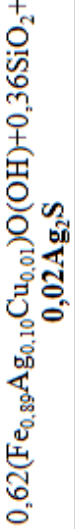 & 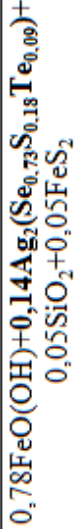 & 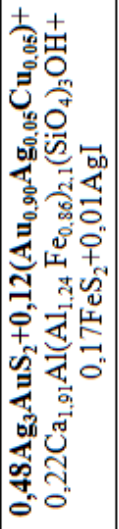 & 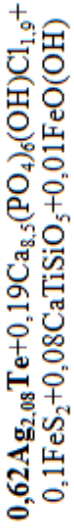 & 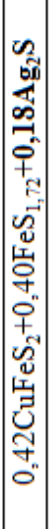 & 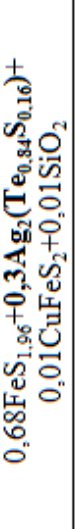 & 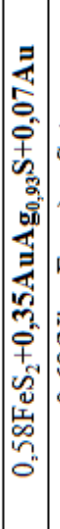 & 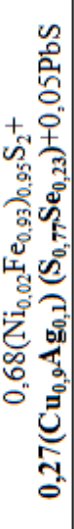 & 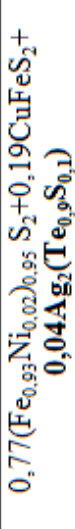 & 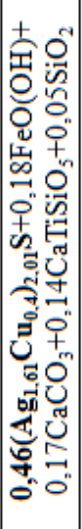 & 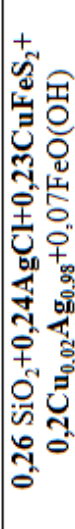 \\
\hline W & $\stackrel{1}{0}$ & 으. & ¿ & ○ & $\stackrel{-}{ }$ & $\stackrel{-}{ }$ & 이 & 이 & 으 & ঃ & 。․ & 으. & 으 & 음 & ¿ \\
\hline 苗 & 1 & 1 & , & ' & , & ' & ' & , & 1 & , & & 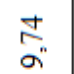 & , & , & \\
\hline 嵒 & 1 & 1 & ' & ' & ' & ' & & ' & , & 1 & & . & ' & & \\
\hline$\mapsto$ & . & 1 & ' & ' & ' & ' & $\begin{array}{c}\text { S. } \\
\text { O" }\end{array}$ & ' & 1 & ' & & , & ' & , & \\
\hline $\mathbb{4}_{4}^{\circ 0}$ & $\begin{array}{c}c \\
\infty \\
\tilde{b}\end{array} \mid$ & $\begin{array}{l}I \\
n^{\circ}\end{array}$ & $\begin{array}{l}\widetilde{\sigma} \\
\stackrel{\Xi}{=}\end{array}$ & 志 & 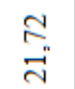 & $\begin{array}{l}\hat{\text { n}} \\
\text { d् }\end{array}$ & $\stackrel{\infty}{\stackrel{\infty}{0}}$ & $\begin{array}{l}g_{2} \\
\text { on } \\
\text { on }\end{array}$ & $\mid \begin{array}{l}\hat{a} \\
\hat{A}\end{array}$ & $\underset{m}{\stackrel{a}{m}}$ & $\left|\begin{array}{l}g \\
\underset{n}{a} \\
\approx\end{array}\right|$ & $\stackrel{\mathbb{N}}{i}$ & $\begin{array}{l}+ \\
\infty \\
n^{\prime}\end{array}$ & $\hat{n}$ & $\begin{array}{l}\infty \\
\infty \\
\sigma^{n}\end{array}$ \\
\hline 寻 & 1 & 1 & , & ' & ' & ' & $\begin{array}{l}\text { ㅇ } \\
\text { on }\end{array}$ & , & 1 & , & 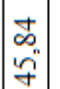 & , & ' & , & \\
\hline$\stackrel{\Perp}{\oplus}$ & 1 & 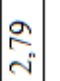 & 1 & . & , & $\stackrel{+}{\stackrel{+}{-}}$ & , & $\begin{array}{l}\infty \\
\stackrel{\infty}{\sim} \\
\stackrel{2}{a}\end{array}$ & . & fo & & & $\stackrel{n}{m}$ & , & \\
\hline$\ddot{n}$ & $\left|\begin{array}{c}\infty \\
\infty \\
+\end{array}\right|$ & 1 & , & , & , & 号 & , & , &. & , & & 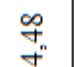 & , & . & \\
\hline$\vec{U}$ & 1 & 1 & , & $\begin{array}{l}\text { হे } \\
\text { ○े }\end{array}$ & , & , & ' & 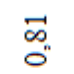 & . & ' & & , & . & ' & $\begin{array}{l}n \\
n \\
n \\
n=1\end{array}$ \\
\hline 泣 & 1 & 1 & , & , & , & , & ' & 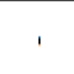 &. & , & & $\begin{array}{l}\text { gे } \\
\text { on }\end{array}$ & 중 & , & \\
\hline$\sim$ & 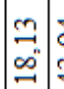 & 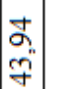 & $\underset{\sim}{\stackrel{\longrightarrow}{\rightleftharpoons}}$ & $\begin{array}{l}\exists \\
\text { ¿ }\end{array}$ & $\vec{\exists}_{-}$ & ले & $\begin{array}{l}\stackrel{2}{a^{\prime}} \\
\text { a }\end{array}$ & $\hat{n}$ & $\left|\begin{array}{c}\hat{2} \\
\Omega^{\prime \prime}\end{array}\right|$ & $\begin{array}{l}\vec{y} \\
\text { गे }\end{array}$ & $\left|\begin{array}{l}0 \\
\infty \\
\tilde{N}^{\prime}\end{array}\right|$ & 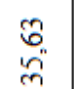 & $\begin{array}{l}\text { 궁 } \\
\text { on }\end{array}$ & $\begin{array}{l}J_{0} \\
0\end{array}$ & $\begin{array}{l}\frac{n}{n} \\
n\end{array}$ \\
\hline O &. & . & , & $\begin{array}{l}\bar{\sigma} \\
\text { ठ̀ }\end{array}$ & $\stackrel{\text { }}{\sim}$ & ' & $\begin{array}{c}\hat{n} \\
\hat{o}\end{array}$ & & $\begin{array}{l}8 \\
8 \\
n^{\prime}\end{array}$ & $\begin{array}{l}\text { क्) } \\
\text { ণै }\end{array}$ & & $\begin{array}{l}\infty \\
\stackrel{\infty}{\circ} \\
\stackrel{\infty}{\lrcorner}\end{array}$ & $\begin{array}{l}n \\
n \\
n\end{array}$ & $\begin{array}{l}\text { வे } \\
\text { ñ }\end{array}$ & 6 \\
\hline م" &. & 1 & ' & , & , & , & 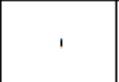 & $\begin{array}{l}0 \\
\stackrel{n}{n}\end{array}$ & . & , & & 1 & , & ' & \\
\hline O্ల & . &. & . & , & 1 & ، & त् & $\begin{array}{l}\infty \\
\stackrel{m}{r}\end{array}$ &. & , & & , & , & $\stackrel{\infty}{\underset{\prime}{\Xi}}$ & \\
\hline 怘 & $\mid$\begin{tabular}{ll}
0 \\
\hdashline \\
\hdashline \\
\hdashline
\end{tabular} & $\begin{array}{l}\hat{n} \\
\sim \\
\gamma\end{array}$ & 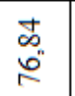 & $\begin{array}{l}\text { ñ } \\
\infty^{\circ}\end{array}$ & నે & $\begin{array}{l}\text { g. } \\
b^{\circ} \\
\mathfrak{n}^{\circ}\end{array}$ & $\begin{array}{l}\text { 'f } \\
\text { fo }\end{array}$ & $\begin{array}{l}\text { nf } \\
\text { fr }\end{array}$ & $\begin{array}{l}\text { Nิ } \\
\text { min }\end{array}$ & $\begin{array}{l}\hat{0} \\
\text { ర్ర }\end{array}$ & $\begin{array}{l}2 \\
\infty \\
\cong \\
=\end{array}$ & $\begin{array}{l}\infty \\
\infty \\
\infty \\
\text { N }\end{array}$ & $\begin{array}{l}\text { ป̄ } \\
\text { ๙̃ }\end{array}$ & 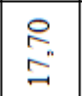 & $\hat{n}$ \\
\hline$\stackrel{O}{m}^{m}$ & ' & . & ' & ' & 1 & & F & 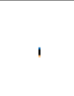 & 1 & 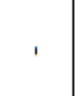 & & , & ' & $\begin{array}{l}\infty \\
\infty \\
\infty^{\prime}\end{array}$ & \\
\hline ○ & . & 1 & , & , & , & & & $\stackrel{\tilde{N}}{\tilde{d}}$ & . & . & & . & , & $\begin{array}{l}\infty \\
\stackrel{\sim}{n}\end{array}$ & \\
\hline$\overbrace{}^{-1}$ & 1 & . & $\underset{\sim}{\infty}$ & , & 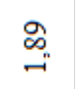 & $\begin{array}{l}n \\
\sim\end{array}$ & $\begin{array}{l}\text { 呆 } \\
\text { nn }\end{array}$ & 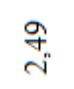 & . & స్రం & & , & 1 & $\hat{n}$ & $\bar{E}$ \\
\hline 年号 & -1 & $\sim$ & $m$ & + & in & 0 & r & $\infty$ & $a$ & 으 & $\exists$ & $\approx$ & $\stackrel{\varrho}{\varrho}$ & \pm & \\
\hline
\end{tabular}

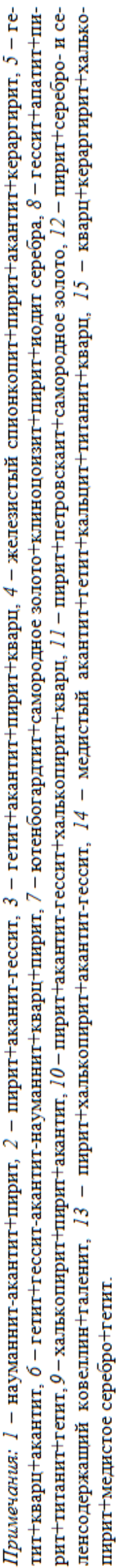


Таблица 5

Химический состав электрума и золота, масс.\%

\begin{tabular}{|c|c|c|c|c|c|}
\hline & $\mathrm{Au}$ & $\mathrm{Ag}$ & $\mathrm{Hg}$ & Сумма & Формула \\
\hline 1 & 76,92 & 24,88 & & 101,8 & $\mathrm{Au}_{0,68} \mathrm{Ag}_{0,32}$ \\
\hline 2 & 53,34 & 43,73 & 2,9 & 99,97 & $\mathrm{Ag}_{0,59} \mathrm{Au}_{0,39} \mathrm{Hg}_{0,02}$ \\
\hline 3 & 83,65 & 15,88 & & 99,53 & $\mathrm{Au}_{0,74} \mathrm{Ag}_{0,26}$ \\
\hline 4 & 83,52 & 16,57 & & 100,09 & $\mathrm{Au}_{0,73} \mathrm{Ag}_{0,27}$ \\
\hline 5 & 83,32 & 15,89 & & 99,21 & $\mathrm{Au}_{0,74} \mathrm{Ag}_{0,26}$ \\
\hline 6 & 83,91 & 15,91 & & 99,82 & $\mathrm{Au}_{0,74} \mathrm{Ag}_{0,26}$ \\
\hline
\end{tabular}

Халькопирит образует изометричные удлиненные выделения в пирите, а также неправильной формы кристаллы в матриксе размером до 100 мкм и более, окруженные каймой гидроокислов железа. По краям халькопирита, иногда на контакте халькопирита и пирита наблюдаются зерна акантита, акантит-гессита и самородного медистого серебра.

Молибденит встречается в виде включений в пирите, эпидоте и в клинопирротине. Размеры чешуек до 4 мкм. Кобальтсодержащий пентландит размером до 15 мкм встречается в никельсодержащем клинопирротине. Галенит, ковеллин-клокманнит, клинопирротин, сфалерит, серебро- и селенсодержащий ковеллин и спионкопит выявлены как изометричные включения размером до 60 мкм в пирите.

Минералы серебра: самородное серебро, акантит, акантит-гессит, гессит, гессит-акантит-науммонит, хлорид и йодид серебра образуют удлиненные, изометричные выделения размером до 7 мкм и ассоциируются с гидроокислами железа, пиритом, халькопиритом и спионкопитом. Они приурочены к трещинам (рис. 4 a), а также к контактовым и ослабленным зонам (рис. 4 б, в, г).

Ютенбогаардтит в ассоциации с высокопробным самородным золотом образуют удлиненные выделения в эпидоте размером до 5 мкм (рис. 5 a).

Петровскаит в срастании с высокопробным самородным золотом и в ассоциации с электрумом размерами до 3 мкм в виде изометричных выделений находится в пирите (рис. 5 б).

Электрум, иногда ртутьсодержащий (табл. 5) содержится в эпидоте и в пирите и имеет размеры до 6 мкм (рис. 5 б, в).

Низкопробное золото встречается в виде изометричных включений в пирите размером до 6 мкм (табл. 5 , рис. 5 г).

\section{Обсуждение результатов}

Наиболее ранний минерал в амфиболитах и сланцах представлен амфиболом - эденитом, который является породообразующим, широко распространен в массивных амфиболитах центральных частей харбейского метаморфического комплекса и фиксирует ранний этап метаморфизма высокотемпературной ступени амфиболитовой фации умеренных давлений [5, 17]. Барруазит, гранат, кварц I и эпидот I в амфиболитах и сланцах, по-видимому, находятся в парагенезисе и характеризуют повторный этап метаморфизма.

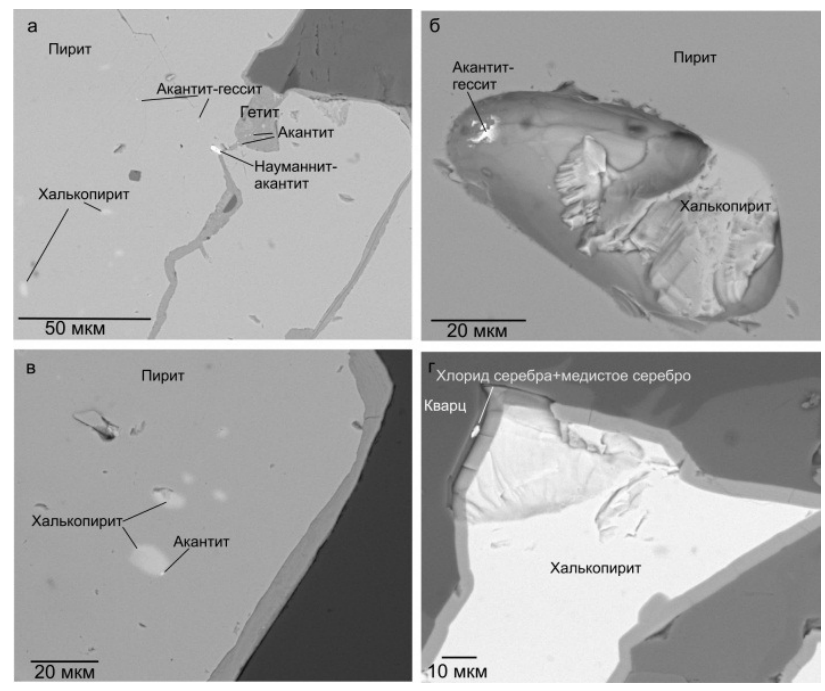

Рис. 4. Минералы серебра, развивающиеся по трещинкам (а) и контактовым зонам (б, в, г).
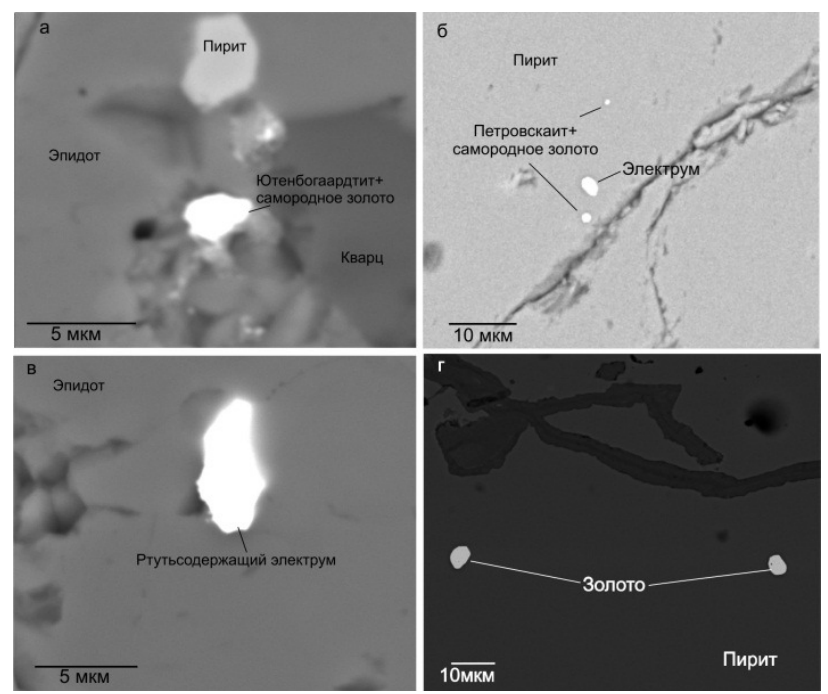

Рис. 5. Минералы золота и серебра в клиноцоизите (а и в) и в пирите (б и г).

Барруазит является переходным по составу от глаукофана к роговой обманке и образуется в отличие от роговых обманок в условиях повышенных давлений [18]. По гранат-амфиболовым геотермометрам [8, 9] максимальное значение вычисленной температуры формирования равно $550^{\circ} \mathrm{C}$ (табл. 6). Согласно амфиболовым геобарометрам [14, 15] пиковое значение давления составляет - 7 кбар. Можно предположить, что барруазит, гранат, эпидот I и кварц I являются продуктами либо низкотемпературной зоны метаморфизма II этапа, фиксирующегося в сланцеватых амфиболитах центральных частей харбейского комплекса [19], либо повторных преобразований III этапа низких ступеней эпидот-амфиболитовой фации повышенных давлений.

На рис. 6 показаны точки распределения составов различных амфиболов из амфиболитов и сланцев по руч. Скалистому, а также точки составов амфиболов 
Таблица 6

Термодинамические параметры образования минералов из пород харбейского комплекса по руч. Скалистому

\begin{tabular}{|c|c|c|c|c|c|c|c|c|c|c|c|c|}
\hline \multirow{3}{*}{$\begin{array}{l}\text { № } \\
\Pi / \Pi\end{array}$} & \multicolumn{2}{|c|}{$\begin{array}{l}\text { Гранат-амфиболовый } \\
\text { геотермометр, Т }\left({ }^{\circ} \mathrm{C}\right)\end{array}$} & \multicolumn{2}{|c|}{$\begin{array}{c}\text { Амфиболовый } \\
\text { геобарометр, Р } \\
\text { (кбар) }\end{array}$} & \multicolumn{8}{|c|}{ Хлоритовый геотермометр, T $\left({ }^{\circ} \mathrm{C}\right)$} \\
\hline & \multirow{2}{*}{ по [8] } & \multirow{2}{*}{ по [9] } & \multirow{2}{*}{ по [14] } & \multirow{2}{*}{ по [15] } & \multicolumn{2}{|c|}{ по [10] } & \multicolumn{2}{|c|}{ по [11] } & \multicolumn{2}{|c|}{ по [12] } & \multicolumn{2}{|c|}{ по [13] } \\
\hline & & & & & $\mathrm{p}$ & $\Pi$ & $\mathrm{p}$ & $\Pi$ & $\mathrm{p}$ & $\Pi$ & $\mathrm{p}$ & $\Pi$ \\
\hline 1 & 430 & 511 & 5,0 & 4,9 & & & & & & & & \\
\hline 2 & 486 & 545 & 5,9 & 5,9 & & & & & & & & \\
\hline 3 & 455 & 521 & 5,1 & 4,9 & 311 & & 253 & & 247 & & 273 & \\
\hline 4 & 473 & 531 & 6,8 & 7,1 & 329 & 234 & 281 & 134 & 262 & 190 & 292 & 176 \\
\hline 5 & 479 & 533 & 4,5 & 4,3 & 335 & & 291 & & 267 & & 299 & \\
\hline 6 & 503 & 549 & 5,0 & 4,9 & 322 & & 271 & & 258 & & 286 & \\
\hline
\end{tabular}

Примечание: 1-3 - амфиболиты, 4-6 сланцы, $p$ - рипидолит, $n$ - пикнохлор.
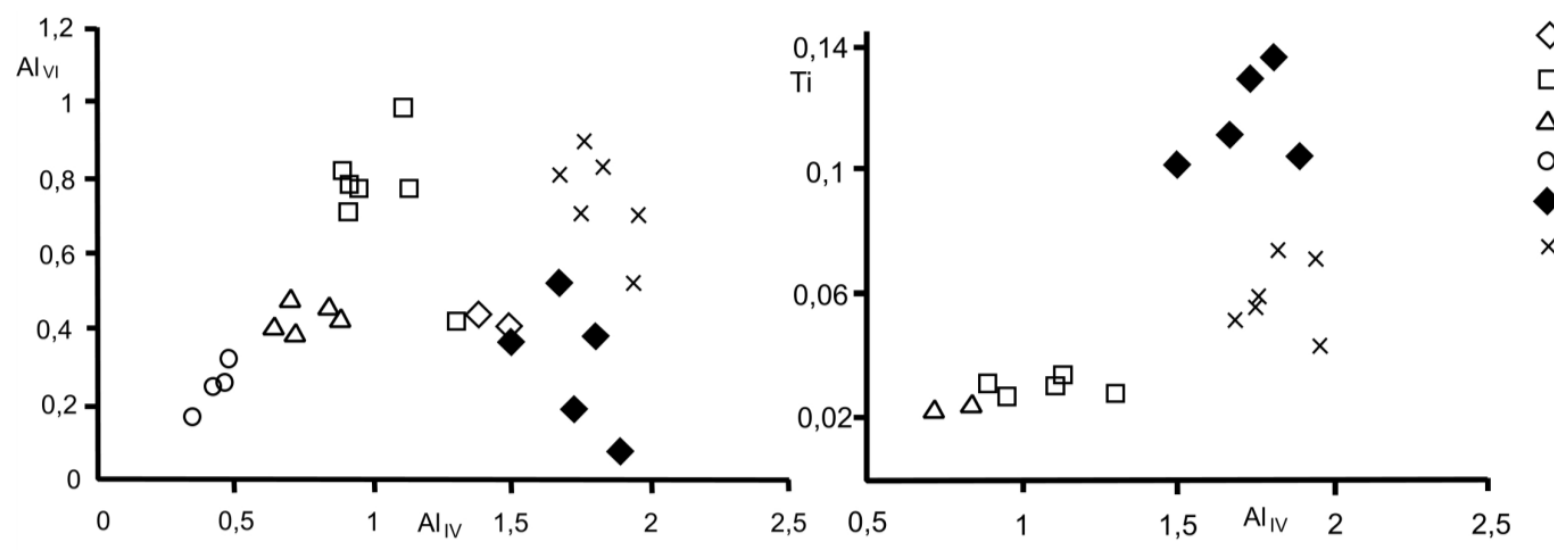

Puc. 6. Точки составов амфиболов на диаграммах $\mathrm{Al}_{\mathrm{IV}}-\mathrm{Al}_{\mathrm{VI}}$ и $\mathrm{Al}_{\mathrm{IV}}-\mathrm{Ti}$ из пород руч. Скалистого (1 - эденит, 2 - барруазит, 3 - магнезиальная роговая обманка, 4 - актинолит) и из массивных (5 - эденит-паргасит-гастинситы) и сланцеватых (6чермакит-паргасит-гастингситы) амфиболитов центральных частей харбейского метаморфического комплекса.

из массивных и сланцеватых амфиболитов [5] центральных частей харбейского комплекса по содержанию $\mathrm{Al}_{\mathrm{IV}}, \mathrm{Al}_{\mathrm{VI}}$ и Ті. Как известно [20], алюминий в октаэдрической позиции и титан увеличиваются при повышении температуры, а алюминий в шестерной координации - при давлении. Самые высокие содержания алюминия в четверной координации имеют амфиболы из массивных и сланцеватых амфиболитов, а также эденит и ферроэденит из пород руч. Скалитого. По содержанию титана доминируют амфиболы из массивных амфиболитов, поэтому они самые высокотемпературные ( $\mathrm{T}-635-790{ }^{\circ} \mathrm{C}$ [5]). Магнезиальная роговая обманка и актинолит образуют непрерывный ряд и, по-видимому, сформировались в один цикл низкотемпературного преобразования пород. Они развиваются локально, приурочены к дислоцированным, хлоритизированным и эпидозитовым участкам. Барруазит и амфиболы из сланцеватых амфиболитов имеют самые высокие значения алюминия в шестерной координации, т. е. они сформировались при повышенном давлении.

Хлорит, кальцит, мусковит, клиноцоизит II, альбит I, альбит II, кварц II, также как и актинолит и магнезиальная роговая обманка в амфиболитах и сланцах являются наложенными образованиями. Содержание их увеличивается в сланцах, участвующих в складча- тости, где имеются ослабленные зоны и проницаемость пород выше. Эти породы отличаются по химическому составу от слабоизмененных амфиболитов, следовательно, вторичные процессы происходили аллохимически, а вновь образованные минералы являются метасоматическими.

Рассмотрим корреляционную зависимость содержаний элементов в породах. Оксид кальция образует положительную корреляцию с диоксидом углерода $(\mathrm{r}$ коэффициент корреляции - 0,74) и окисным железом $(\mathrm{r}-0,70)$, поэтому повышение его содержаний в породе связано с кальцитизацией и клиноцоитизацией. Алюминий положительно коррелирует с натрием (r 0,44), поэтому, мусковитизация, скорее всего, сопровождала альбитизацию.

Так как количество сульфатной серы в каждом образце меньше $0,05 \%$, то в состав общей серы входит, по-видимому, в основном сульфидная сера. Сера образует положительную корреляцию с кремнеземом $(\mathrm{r}-0,76)$ и оксидом натрия $(\mathrm{r}-0,49)$, также слабую положительную корреляцию с закисным железом $(\mathrm{r}-0,30)$ и магнием $(\mathrm{r}-0,30)$, но отрицательную корреляцию с оксидом кальция $(\mathrm{r}--0,76)$. Из этого следует, что сульфиды отлагались на стадии хлоритизации и альбитизации, но в большей части при процессах окварцевания. Хлорит, актинолит и 
магнезиальная роговая обманка, скорее всего, сформировались под воздействием тех же низкотемпературных растворов, что привели к метасоматическим изменениям амфиболиты.

Согласно хлоритовым геотермометрам [10-13] получены два диапазона температур: по рипидолиту $245-335^{\circ} \mathrm{C}$, по пикнохлору $-135-235^{\circ} \mathrm{C}$, что, возможно, указывает на два этапа формирования низкотемпературных минералов (табл. 6).

Процессы преобразования пород по руч. Скалистый можно представить в следующей последовательности: метаморфизм высоких ступеней амфиболитовой фации (эденит), метаморфизм эпидотамфиболитовой фации повышенных давлений (гранат, барруазит, кварц I, клиноцоизит I) -наложенные процессы: альбит I + актинолит + магнезиальная роговая обманка + клиноцоизит II + кальцит + хлорит + мусковит (Ca, Na и K метасоматоз) - альбит II ( $\mathrm{Na}$ метасоматоз) - кварц II (Si метасоматоз) - развитие кальцитовых, кварц-кальцитовых и кварцевых жил.

Электрум, золото, ютенбогаардтит и петровскаит ассоциируют с пиритом и эпидотом и являются, скорее всего, гипогенными минералами, образовавшимися при воздействии низкотемпературных гидротерм. Низкотемпературные минералы - акантит, гессит, акантит-гессит, науммонит-акантит, гесситакантит-науммонит, хлорид и йодид серебра, а также самородное серебро ассоциируют с гетитом, приурочены к трещинам и сформировались, по-видимому, позднее, в гипергенных условиях в зонах окисления сульфидов.

\section{Заключение}

Породы харбейского метаморфического комплекса по руч. Скалистому представлены в различной степени измененными амфиболитами. Они претерпели метаморфизм высоких ступеней амфиболитовой фации умеренных давлений и эпидотамфиболитовой фации повышенных давлений. Процессы клиноцоитизации, кальцитизации, хлоритизации, альбитизации, мусковитизации и окварцевания происходили с изменением химического состава пород в результате кальциевого, натриевого, калиевого и кремниевого метасоматоза. Сульфидизация пород тесно связана с окварцеванием. Низкотемпературные метасоматические преобразования пород проходили минимум в два этапа. С низкотемпературными растворами, скорее всего, также связано появление рудной ассоциации самородного золота, электрума, ютенбогаардтита и петровскаита. Халькогениды, йодит и хлорид серебра, а также самородное серебро образовались при гипергенных процессах.

Автор выражает благодарность за помощь $и$ консультацию д.г.-м.н., профессору А. М. Пьстину и д.г.-.м.н. В. И. Силаеву, к.г.-м.н. Р. И. Шайбекову, а также Е.М. Тропникову и А. С. Шуйскому.
Исследования проведены в рамках НИР ИГ Коми НЦ УрО РАН ГР № АААA-A17-117121270035-0, а также при поддержке Программы фундаментальных исследований РАН № 18-5-5-19.

\section{ЛИТЕРАТУРА}

1. Душин, В. А. Активизированные шовные зоны - новый перспективный объект благороднометалльной металлогении на Полярном Урале / В. А. Душин // Региональная геология и металлогения - 2006. - № 29. - С. 73-87.

2. Савельева, К. П. Золотое оруденение нетрадиционного типа в зоне Серовско-Маукского глубинного разлома на Северном Урале / К. П. Савельева, А. Г. Баранников // Литосфера .- 2006. - № 2. - С. 157-166.

3. Государственная геологическая карта Российской Федерации. Масштаб $1: 200$ 000. Издание второе. Серия Полярно-Уральская. Лист Q-42-VII, VIII (Обской). Объяснительная записка. / В. А. Душин [и др.] // СПб.: Картографическая фабрика ВСЕГЕИ, 2014. - 384 с.

4. Колганов, Е. Р. Золотоносность Париквасьшорского участка / Е. Р. Колганов, И. О. Алексеенок, В. А. Тельтевский // Материалы международной научно-практической конференции «Уральская горная школа - регионам». Екатеринбург, 2011. - С. 13-14.

5. Уляшева, Н. С. Метабазиты харбейского комплекса (Полярный Урал) / Н. С. Уляшева; отв. ред. А. М. Пыстин. Сыктывкар: Геопринт, 2012. - 98 с.

6. Пыстина, Ю. И. Цирконовая летопись уральского докембрия / Ю. И. Пыстина, А. М. Пыстин. - Екатеринбург: УрО PAH, 2002. $-168 \mathrm{c}$.

7. Краснобаев, А. А. Циркон как индикатор геологических процессов / А. А. Краснобаев. - М.: Наука, 1986. - 152 с.

8. Graham, C. M., A garnet-hornblende geothermometer: calibration, testing, and application to the Pelona Schist, Southern California. / C. M. Graham, R. Powell // J. Metamorf. Geol. 1984. - V.2. - N.1. - P. 33-42.

9. Perchuk, L. L., Some equilibria in volving garnet, orthopyroxene and amphibole as geothermometers and geobarometers for metamorphic rocks / L. L. Perchuk, I. V. Lavrent'eva // Experiment-89, Informative volume. - Moscow: Nauka, 1990. - P. 44-45.

10. Cathelineau, M. Cation site occupancy in chlorites and illites as function of temperature / M. Cathelineau // Clay Miner. 23. 1988. - P. 471-485.

11. Hillier, S. Octahedral occupancy and chemical composition of di- agenetic (low-temperature) chlorites / S. Hillier, B. Velde // Clay Miner. 26. - 1991. - P.149-168.

12. Zang, $W$. Chloritization of the hydrothermally altered bedrock at the Igarapé Bahiago lddeposit, Carajás, Brazil. / W. Zang, W. S. Fyfe // Mineral. Depos. 30. - 1995. - P. 30-38.

13. Xie, X. IIb trioctahedral chlorite from the Barberton greenstone belt: crystal structure and rock composition constraints with implications to geothermometry / X. Xie, G. R. Byerly, R. E. J. Ferrell Jr // Contrib. Mineral. Petrol. 126. - 1997. - P. 275-291.

14. Schmidt, M. W. Experimental calibration of the Al-inhornblende geobarometer at $650{ }^{\circ} \mathrm{C}, 3.5-13.0 \mathrm{kbar} / \mathrm{M}$. W. Schmidt // Terra abstracts. - 1991. - V. 3. - №. 1. - P. 30.

15. Hollister, L. S. Confirmation of the Empirical Calibration of $\mathrm{Al}$ in Hornblende with Pressure of Solidification of CalcAlkaline Plutons / L. S. Hollister [et al.] // American Mineralogist. - 1987. - V. 72. - №. 3-4. - P. 231-239.

16. Leake, B. E. Nomenclature of amphiboles: report of the subcommittee on amphiboles of the international mineralogical association, commission on new minerals and mineral names / 
B. E. Leake [et al.] // The Canadian Mineralogist. - 1997. - V. 35. - P. 219-246.

17. Глубинное строение Тимано-Североуральского региона / Отв. редактор А. М. Пыстин. - Сыктывкар: Геопринт, 2011. $-264 \mathrm{c}$.

18. Костюк, E. A. Статистический анализ и парагенетические типы амфиболов метаморфических пород / Е. А. Костюк - М.: Наука, 1970. - 312 с.

Институт геологии имени академика Н. П. Юшкина Коми научного иентра Уральского отделения Российской академии наук, г. Сыктывкар

Уляшева Наталия Сергеевна, научный сотрудник, кандидат геолого-минералогических наук

Email:nsulasheva@geo.komisc.ru

тел.: +7 (821) 2245353
19. Уляшева, Н. С. Термодинамическая эволюция метаморфизма пород харбейского комплекса (Полярный Урал) / Н. С. Уляшева // Вестник Института геологии Коми НЦ УрО РАН. - 2011. - № 9. - С. 2-6.

20. Костюк, E. A. Парагенетические типы амфиболов ряда роговая обманка-актинолит в метаморфических породах / Е. А. Костюк, В. С. Соболев // Докл. АН СССР. - 1965. - Т. 164. - № 4. - C. 898-901.

Institute of Geology of Komi Science Centre of the Ural Branch of the Russian Academy of Sciences, Syktyvkar

Ulyasheva N. S., research fellow, Candidate of Geological and Mineralogical Sciences

Email: nsulasheva@geo.komisc.ru

Tel.: +7 (821) 2245353 